\title{
PKM Sosialisasi Biokontrol Larva Nyamuk Aedes Aegypty dengan Ikan Cupang (Betta splendens) dalam Upaya Pencegahan Penyakit Demam Berdarah Dengue (DBD) di Asrama Putri Fakultas Kesehatan Pondok Pesantren Nurul Jadid
}

\author{
Setiyo Adi Nugroho1, Abdur Rahman², Riski Fatholla ${ }^{3}$, \\ Zaitun Mustaqimah ${ }^{4}$, Siti Zainab ${ }^{5}$
}

Fakultas Kesehatan Universitas Nurul Jadid, Probolinggo ${ }^{12345}$

\{setiyo666@gmail.com ${ }^{1}$, ar9307294@gmail.com ${ }^{2}$, Rizkifathollah@gmail.com ${ }^{3}$, zainatunmustaqima@mail.com ${ }^{4}$, sitizainab1005@gmail.com ${ }^{5}$ \}

\author{
Submission: 23/08/2021 Received: 31/12/2021 Published: 31/12/2021
}

Keywords:

Keyword 1,

Keyword 2,

Keyword 3

Katakunci:

Demam Berdarah, Ikan Cupang, Santri

\begin{abstract}
Islamic boarding schools are at risk of experiencing Experiencing Evwnts (KLB) of season dengue fever, which will cause illness and even death to students. This is caused byenvironmental factors that can be a breeding ground for the Aedes aegybti mosquito. It is important to carry out preventive activitis rather than curative activities that are guided by science, such as this college Real Work Lecture (KKN) activity. This KKN is carried out using methods that include: (1) identification stages including: jumantik Program in callage, student at traditional muslim school knowledge, andenvirinmental obdervation (2) the activity stages is in the form of jumantik training, socialization to students and the distribution of betta fish seeds, and (3) evaluation stage. As the activity design that we have arranged, the results obtained are an increase in students understanding of the environmental impact of the occurrence of DHF, students and jumantik cadres can eradicate mosquito larvae by using enviromentally friendly betta fish (Betta sp) biocontrol, larva-free rates in An-Nafi'iyah Dormitory yeah achieved. It can be concluded that the approach to preventing DHF by eradicating mosquito larvae using betta fish (Betta sp) biocontrol is effective for students at Islamic Boarding Schools. Betta fish cultivation can be used by students so that apart from being a mosquito larvae biocontrol, it can also add economic value.
\end{abstract}

\footnotetext{
Abstrak. Pondok pesantren berisiko mengalami Kejadian Luar Biasa (KLB) penyakit musiman Demam Berdarah, yang akan menyebabkan kesakitan bahkan kematian kepada santri. Hal ini diakibatkan karena faktor Lingkungan yang dapat menjadi perkembangbiakan nyamuk aedes aegypti. Penting untuk dilakukan kegiatan prefentif dibandingkan kuratif yang berpedoman kepada ilmu pengetahuan, seperti halnya kegiatan Kuliah Kerja Nyata (KKN) Perguruan Tinggi ini. KKN ini dilakukan dengan metode yang meliputi: (1) tahap identifikasi diantaranya: Program Jumantik Di Pondok, Pengetahuan santri, dan observasi lingkungan; (2) Tahap kegiatan berupa pelatihan Jumantik, sosialisasi kepada santri dan penebaran bibit ikan cupang; serta (3) Tahap evaluasi. Sebagaimana rancangan kegiatan yang telah kami rangkai, didapatkan hasil peningkatan pemahaman santri tentang dampak lingkungan akan terjadinya DBD, santri dan kader Jumantik dapat melakukan pemberantasan jentik nyamuk dengan menggunakan biokontrol ikan cupang (Betta sp) yang ramah lingkungan, angka bebas jentik di Asrama An-Nafi'iyah
} 
tercapai. Dapat disimpulkan bahwa pendekatan pencegahan Penyakit DBD dengan memberantas jentik nyamuk menggunakan biokontrol ikan cupang (Betta $s p$ ) efektif dilakukan bagi santri di Pondok Pesantren. Budidaya ikan cupang dapat dipergunakan santri sehingga selain sebagai biokrontrol jentik nyamuk, juga dapat menambah nilai ekonomi.

\section{Pendahuluan}

\section{Analisa Situasi}

Demam Berdarah Dengue (DBD) atau biasa juga dikenal sebagai Dengue Fever disebabkan oleh nyamuk Aedes Aegypti yang berkembang di daerah tropis dan subtropis, merupakan salah satu penyakit menular yang dapat menimbulkan wabah. Penyakit ini merupakan salah satu masalah kesehatan di Indonesia yang dapat menimbulkan kehawatiran karena perjalanan penyakitnya yang cepat dan dapat menyebabkan kematian dalam waktu singkat (Amelia et al., 2020). DBD banyak dijumpai dari aspek kesehatan lingkungan diantaranya system drainase terbuka dan banyak sampah, sampah plastik ditaman menyebabkan genangan air akibat menyiram bunga, adanya bunga hias menggunakan media air dan atas pot menyimpan genangan air, adanya tempat pakan ternak yang berisi air, tempat minum burung berkicau yang jarang dibersihkan (Tahir \& Kenre, 2021).

Upaya pencegahan hidup nyamuk akan lebih lama bila tingkat kelembaban tinggi, seperti selama musim hujan (Nazri et al., 2013). Curah hujan dapat menambah jumlah tempat perkembangbiakan vektor (breeding places) atau dapat pula menghilangkan tempat perindukan. Curah hujan dapat juga berpengaruh terhadap suhu dan kelembaban nisbi udara. Menurut Cahyati (2006) bahwa curah hujan 140 mm/minggu dapat menghambat berkembangbiaknya nyamuk. Curah hujan yang lebat menyebabkan bersihnya tempat perindukan vektor oleh karena hanyut terbawa aliran air yang menyebabkan matinya larva/jentik nyamuk (Kusumawati et al., 2021).

Berdasarkan beberapa hasil penelitian yang telah dilakukan, ikan cupang menunjukkan kemampuan yang berbeda dalam mengendalikan larva nyamuk(Taviv et al., 2010). Menunjukkan bahwa ikan cupang (Betta sp.) yang efektif untuk pengendalian larva Aedes aegypti adalah ikan dengan ukuran $4 \mathrm{~cm}$ atau $5 \mathrm{~cm}$. Ikan cupang tidak mati walaupun di kontainer terdapat atau ditaburi abate. Selanjutnya terbukti bahwa pemanfaatan ikan cupang (Betta sp.) plus pemantau jentik lebih efektif meningkatkan Angka Bebas Jentik (ABJ) dan menurunkan House Index (HI), Container Index (CI), 
Breteau Index (BI) dibandingkan hanya dengan pemantau jentik (Harsono, 2019).

Santri Dipondok Pesantren Nurul jadid memiliki resiko terjadinya DBD, Hal ini disebebkan populasi yang sangat besar dengan jumlah santri 7.556 pada tahun 2021 .Berdasarkan data penelitian yang dilakukan oleh Ahmad Kholid Fauzi melaporkan bahwa PHBS santri di Pondok Pesantren Nurul Jadid sangat rendah (Fauzi, 2018). Serta bayaknya genangan Air Diselokan dan Kamar Mandi yang beresiko menjadi sarang nyamuk. Pondok Pesantren Sudah Melakukan Program JUMANTIK yang dikelola oleh klinik Az-zainiyah, Program JUMANTIK yang selama ini dilaksanakan hanya sebatas Pemeriksaan jentik dan sosialisasi PHBS bagi santri. Program JUMANTIK ini belum menyentuh bagaimana pemeberantasan jentik nyamuk dengan Biokontrol Ikan Cupang yang ramah lingkungan.

\section{Alasan Memilih Program}

Kegiatan Pengabdian Masyarakat ini dilakukan karena:

1. Santri Pondok Pesantren Nurul jadid berisiko terjadinya kejadian DBD dikarnakan populasi yang begitu besar yg masih minim PHBS

2. Banyaknya genangan air yang berisiko menjadi sarang nyamuk di Pondok Pesantren Nurul Jadid

3. Adanya program JUMANTIK yang kurang efektif dalam pencegahan DBD di Pondok Pesantren Nurul Jadid Dikarenakan kurangnya Pengetahuan tentang penanganan DBD

4. belum adanya Penggunaan Biokontrol

Sosialisasi ini penting dilakukan untuk mengefektifkan Program JUMANTIK dan Mengontrol popuslasi jentik nyamuk di Pondok Pesanten Nurul Jadid. Sebagai percontohan dilakukan di Asrama AnNafi'iyah. 


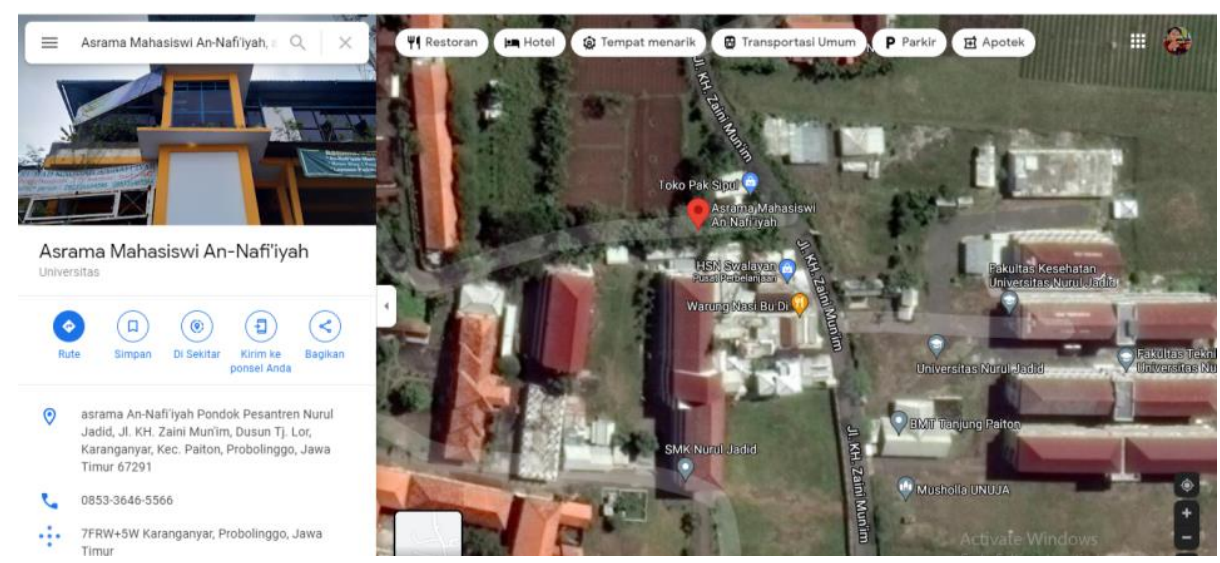

Gambar: Lokasi Pengabdian masyarakat

\section{Metode Pelaksanaan}

\section{Ringkasan Metode Pelaksanaan}

1. Tahap Identifikasi

Kegiatan PKM ini dilaksanakan dengan mengidentifikasi lokasi diAsrama An-Nafi'iyah. Identifikasi dlakukan:

a. Mengetahui Program dari JUMANTIK.

b. Untuk mengetahui tingkat pengetahuan JUMANTIK tantang DBD dan Biokontrol Menggunakan Ikan Cupang.

c. Untuk Mengetahui resiko tempat tumbuhnya jentik nyamuk di asrama An-Nafi'iyah.

2. Tahap kegiatan

Kegiatan Pengabdian Masyarakat ini dibagi menjadi 3 kegiatan:

a. Pelatihan JUMANTIK

Pada Kegiatan pelatihan JUMANTIK ini diselenggarakan melalui media ZOOM dikarenakan adanya PPKM, yang pematerinya langsung dari Dinas Perikanan Kab.probolinggo dan dosen fak. kesehatan yang membahas tentang Biokontrol Ikan Cupang dan pelatihan Kader JUMANTIK serta mengenai DBD yang di ikuti oleh peserta KKN.

b. Sosialisi Biokontrol Ikan Cupang

Kegiatan Sosialisasi ini dilakukan di Asrama An-nafi'iyah oleh peserta KKN untuk memberikan pengetahuan tentang Biokontrol Ikan Cupang Dalam mengurangi populasi jentik nyamuk di Asrama An-Nafi'iyah. 
c. Penyebaran Bibit Ikan Cupang

Penyebaran bibit ikan cupang dilakukan oleh peserta KKN di Kamar mandi dan genangan air di Asrama An-Nafi'iyah

\section{Tahap Evaluasi Kegiatan}

Pada tahap ini kami akan mengevaluasi kegiatan yang sudah kami laksanakan, hasil dari kegiatan tersebut banyak peserta yang berantusias mengikuti kegiatan dari awal sampai akhir dan juga melakukan penyebaran ikan cupang di kamar mandi santri dan kolam ikan. Pemeliharaan ikan tersebut untuk pemberantasan jentik yang meningkat dengan memutus siklus hidup nyamuk Aedes aegypti sehingga kepadatan populasi serta regenerasi nyamuk akan berkurang.

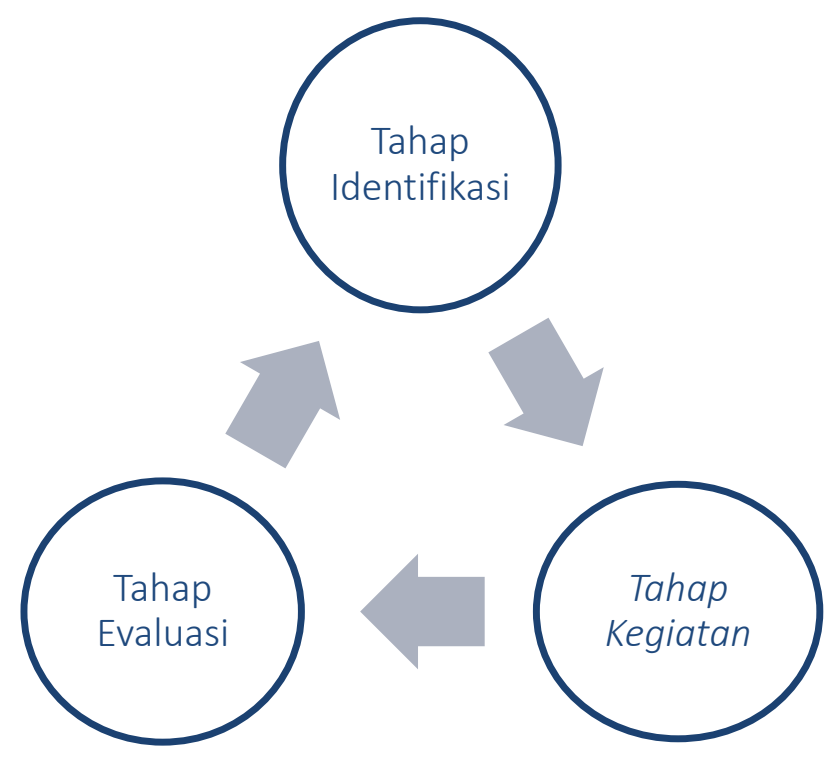

\section{Tempat dan Waktu Pelaksanaan}

Pelaksanaan pengabdian diadakan di Asrama An-Nafi'iyah. program diawali dengan koordinasi antara dosen Universitas Nurul Jadid, Tim Jumantik dan santri di asrama An-Nafi'iyah pada juni 2021 hingga agustus 2021. 


\begin{tabular}{|c|l|l|l|l|}
\hline \multirow{2}{*}{$\begin{array}{c}\text { Tahapan } \\
\text { Kegiatan }\end{array}$} & \multicolumn{3}{|c|}{ Bulan Juni-Agustus } \\
\cline { 2 - 5 } & Bulan ke-1 & Bulan ke-2 & Bulan ke-3 & Bulan ke-3 \\
\hline Identifikasi & & & & \\
\hline Kegiatan pelatihan & & & & \\
\hline Kegiatan sosialisai & & & & \\
\hline Kegiatan penyebaran bibit & & & & \\
\hline Evaluasi & & & & \\
\hline Penulisan laporan & & & & \\
\hline Publikasi & & & & \\
\hline
\end{tabular}

\section{Manfaat Program}

Adapun Manfaat dari sosialisasi budidaya ikan cupang dalam mengurangi populasi jentik nyamuk:

1. Membantu santri untuk mengetahui pemanfaatan ikan cupang sebagia biokontrol jentik nyamuk berbasis ramah lingkungan.

2. Pemberantasan jentik nyamuk di kawasan Pondok Pesantren Nurul Jadid.

3. Pencegahan terjadinya DBD di Pondok pesantren Nurul Jadid.

4. Menambah wawasan dan pengetahuan kepada santri. 
Pihak-Pihak yang Dilibatkan dalam Program

\begin{tabular}{|c|c|c|}
\hline No & Stakeholder & Dukungan \\
\hline 1. & \multicolumn{2}{|l|}{ Asrama An-Nafi'iyah } \\
\hline 2. & $\begin{array}{l}\text { a. Kepala Wilayah Asrama } \\
\text { Fakultas Kesehatan }\end{array}$ & $\begin{array}{l}\text { Memberikan informasi dan masukan seput } \\
\text { ar lokasi dimana saja untuk dilakukan } \\
\text { Penyebaran ikan cupang sebagai biokontrol } \\
\text { mengurangi jentik nyamuk sehingga angka } \\
\text { penyakit DBD berkurang. }\end{array}$ \\
\hline 3. & b. Santri & $\begin{array}{l}\text { Saling memberikan informasi kepada teman } \\
\text { kamarnya, untuk mencegah penyakit DBD } \\
\text { dengan membudidaya ikan cupang. }\end{array}$ \\
\hline 4. & c. LP3M & $\begin{array}{l}\text { Sebagai pemberi program KKN Fakultas } \\
\text { Kesehatan Universitas Nurul Jadid }\end{array}$ \\
\hline 5. & d. Fakultas Kesehatan & Pelaksana program tim KKN \\
\hline
\end{tabular}

\section{Hasil dan Pembahasan}

\section{Proses Pelaksanaan PKM}

Sebagai langkah awal yaitu mengidentifikasi, tim KKN melakukan wawancara kepada santri akan program JUMANTIK yang telah dilaksanakan didapat hasil bahwa selama ini belum ada penanganan khusus tentang pemberantasan sarang nyamuk yang selama ini dilakukan oleh Tim JUMANTIK hanya sebatas penyuluhan kesehatan, dentifikasi selanjutnya mengenai pengetahuan santri tentang bahaya penyakit DBD yang disebabkan oleh nyamuk aides aigypti didapatkan hasil pengetahuan yang rendah dan cukup, sedangkan pada saat pemantauan oleh Tim KKN didapatkan hasil bahwa terdapat jadwal rutin pembersihan bak mandi satu minggu sekali akan tetapi secara pelaksanaan belum optimal sehingga ditemukan beberapa jentik nyamuk di bak mandi santri, Hal inilah yang menjadi resiko besar bagi santri akan bahayanya DBD dan dari temuan tersebut membuktikan bahwasanya belum tercapainya Angka Bebas Jentik (ABJ)

Sebagaimana kegiatan yang telah kami rangkai dalam langkah Pemanfaatan Ikan Cupang Sebagai Biokontrol Dalam Pencegahan Penyakit 
Demam Berdarah Dengue (DBD) Di Asrama Putri Fakultas Kesehatan ( Asrama An-Nafi'iyah). Program KKN di adakan sebagai langkah pengabdian kepada santri yaitu dalam bentuk kegiatan sosialisasi dan pemberantasan Nyamuk DBD yang dilaksanakan diasrama fakultas Kesehatan berupa kunjungan. Kunjungan pada kelompok santri dengan melakukan wawancara berupa cara mencegah DBD melalui prilaku hidup sehat. Dari hasil kunjungan dapat disimpulkan bahwa santri belum pernah melakukan pencegahan DBD dengan cara biokontrol ikan cupang, karena santri belum pernah mencoba program tersebuat dan santri belum mengatahui terkait pemanfaatan dari ikan cupang yang dalam hal ini juga dapat mencegah penyakit DBD, maka peserta KKN berinisiatif untuk mengadakan kegiatan sosialisasi untuk pengetahuan baru kepada santri Fakultas Kesehatan dan cara untuk mencegah DBD dengan melakukan pemanfaatan ikan cupang sebagai biokontrol jentik nyamuk Aedes Aegipty.

Berdasarkan informasi yang didapat menyatakan bahwa peningkatan kasus Demam Berdarah Dengue (DBD) dipengaruhi aspek mutu layanan dan aspek kesehatan lingkungan (Susanti et al., 2021). Hal tersebut didukung dengan hasil kunjungan lapangan ditemukan bahwa sosialisasi dan ceramah masih dilakukan oleh tenaga kesehatan. Pemanfaatan ikan sebagai predator alami larva nyamuk adalah salah satu cara pengendalian secara biologi dan ramah lingkungan serta mudah dilakukan oleh santri.

Dalam kegiatan ini peserta KKN mendokumentasikan dan mengevaluasi kegiatan-kegiatan yang sudah terlaksana, yaitu sosialisasi dan penebaran ikan cupang sebagia biokontrol larva nyamuk yang disebarkan di tempattempat sebagai sumber perkembangbiakan larva nyamuk.

\section{Faktor pendukung dan Penghambat}

Terlaksananya kegiatan yang kami rencanakan bukan berarti berjalan dengan sempurna. Meskipun target waktu terselesaikannya program telah tercapai dan sesuai dengan tujuan kami, namun terdapat faktor-faktor yang mempengaruhi berjalannya kegiatan yang direncanakan, diantaranya adalah sebagai berikut:

\section{Faktor Pendukung}

Faktor pendukung dalam pelaksanaan kegiatan ini adalah :

a. Kegiatan ini didukung penuh oleh pondok pesantren hal ini dikarenakan pondok pesantren mempunyai tujuan para 
santri dalam mencari ilmu di pesantren mecapai derajat kesehatan yang sabaik-baiknya.

b. Antusiasme santri terhadap ilmu pengetahuan karena santriwati yg berada di asrama An-Nafi'iyah termasuk mahasiswa fakultas kesehatan.

c. Mudah dan terjangkaunya harga ikan cupang.

d. Tanggapan baik dan sikap yang terbuka serta partisipasi aktif dari santriwati kepada peserta KKN.

\section{Faktor Penghambat}

Faktor penghambat kegiatan ini adalah :

a. Keterbatasan komunikasi serta keterbatasan pertemuan secara tatap muka dikarenakan kondisi pendemi Covid-19.

b. Keterbatasan fasilitas pada pelaksanaan pelatihan dengan zoom meeting.

\section{Kesimpulan}

Dari kegiatan Kuliah Kerja Nyata ini Didapatkan bahwa pendekatan pencegahan Penyakit DBD dengan memberantas jentik nyamuk menggunakan biokontrol ikan cupang (Betta sp) efektif dilakukan bagi santri di Pondok Pesantren.

\section{Pengakuan}

Terimaksih atas kami sampaikan kepada Universitas Nurul Jadid khususnya Lembaga Penebitan Penelitian, dan Pengabdian Masyarakat (LPPPM) yang telah memfasilitasi penelitian ini dikemas dalam program Kulia Kerja Nyata berbasis luaran.

\section{Referensi}

Amelia, K., Asril, L. O., \& Febrianti, L. (2020). Pemodelan Incident Rate Demam Berdarah Dengue Di Indonesia Yang Berkaitan Dengan Faktor Lingkungan Menggunakan Metode Geographically Weighted Regression (Gwr). Ekologia : Jurnal IImiah IImu Dasar Dan Lingkungan Hidup, 20(2), 64-73. 
Fauzi, A. K. (2018). Pengaruh Intervensi Promosi Kesehatan Metode Sorogan Dan Peer Education Terhadap Perilaku Cuci Tangan Pakai Sabun (CTPS) Dengan Pendekatan Health Promotion Model (HPM) di Pondok Pesantren (Studi Pada Santri Pondok Pesantren Nurul Jadid Paiton Probolinggo) [Universitas Airlangga]. http://repository.unair.ac.id/id/e print/77159

Harsono, S. (2019). Metode Biokontrol Ikan Cupang (Betta splendens) Sebagai Pengendali Vektor Penyakit DBD di Kartasura Kabupaten Sukoharjo. Jurnal Manajemen Informasi Dan Administrasi Kesehatan (JMIAK), 2(2), 3-4. https://doi.org/10.32585/jmiak.v2i02.455

Kusumawati, A., Ayu, A. K., Saputri, A. M., Putriadi, P. B., Qurrohman, M. T., \& Dewi, N. (2021). Edukasi Cara Menjadi Jumantik Mandiri Untuk Mencegah DBD Di Tengah Pandemi Covid-19 Pada Kader Posyandu Di Dusun Jetis, Bakungan, Karangdowo, Klaten. LOGISTA - Jurnal IImiah Pengabdian Kepada Masyarakat, 5(1), 147-152.

Nazri, C. D., A., H., I, R., Hassan, A., \& Yazid, A. A. (2013). Utilization of geoinformation tools for dengue control management strategy: a case study in Seberang Prai, Penang Malaysia. International Journal of Remote Sensing Applications, 3(1), 11-17.

Susanti, R. D. D., Hefniy, Agustin, Y. D., \& Nugroho, S. A. (2021). Hubungan Tingkat Pengetahuan Dengan Sikap Keluarga Penderita Demam Berdarah Dengue Tentang Pemberantasan Sarang Nyamuk (PSN) Di Wilayah Kerja Puskesmas Curahdam. Jurnal Keperawatan Profesional, 9(1), 18-35.

Tahir, M., \& Kenre, I. (2021). Penyuluhan dan Pemberantasan Nyamuk Demam Berdarah Dengue (DBD) Kelurahan Rijang Pittu Kabupaten Sidrap. Journal of Community Engagement in Health, 4(1), 254-258. https://doi.org/https://doi.org/10.30994/jceh.v4i1.168

Taviv, Yulian, Saikhu, Akhmad, \& Sitorus, H. (2010). Pengendalian DBD Melalui Pemanfaatan Pemantau Jentik Dan Ikan Cupang Di Kota Palembang. Buletin Penelitian Kesehatan, 34(1), 126-328. 